\title{
くさび形かど点の電界異常性とその緩和方法
}

\author{
正員河本 正* 正員宅間 董**
}

\section{Abnormality of Electric Field at a Wedge-like Edge of a Conductor or a Dielectric Interface and its Relaxation Methods}

Tadashi Kawamoto*, Member, Tadasu Takuma**, Member

\begin{abstract}
Abnormal electric field appears at a wedge-like edge of a conductor(electrode) or a dielectric interface, which usually becomes infinitely high. This paper analyses the electric field near such an edge by the analytical variable separation method and by the numerical one of the charge simulation method. The analysis focuses on the special conditions where the electric field becomes zero at an edge. These conditions are important for the insulation design to suppress the discharge inception at such edges of conductors and dielectric interfaces.
\end{abstract}

キーワード : 静電界, 誘電体, かど点, 絶縁, 電荷重畳法

Keywords : electrostatic field, dielectrics, wedge-like edge, insulation, charge simulation method

\section{1. まえがき}

導体の表面形状と表面電界とは密接な関係がある。導体 が丸みのないかどを有すると, 二次元配置ではくさび形の 形状になるが，その先端の電界は通常理論的に無限大にな ることはよく知られている。一方, 2 種類の誘電体の界面 (境 界）がくさび形のかどになるときも，やはり先端電界が理 論的には通常無限大になる。二次元配置は現実にはありえ ないが，くさび状のかどのごく近くの電界分布を考えると きは，二次元と考えてよい。

絶縁性能面からはこのような無限大の電界は望ましくな いが，配置によってはこれを０にすることができる。実用 面ではかどの電界を０あるいは低い值にできれば，導体や 誘電体にかどがあっても放電の発生を抑制できる可能性が ある。また逆に高電界が必要な場合に電界を低下させる配 置を回避することも考えられる。このような電界緩和の現 象はこれまで理論的にはある程度解析されていたが，実際 にはよく知られていなかった。本論文は，かど点の電界分 布を解析的に調べるとともに, 先端電界が 0 になる条件を 初めて数值的に確かめたものである。なお, 複合誘電体の

\footnotetext{
* (財) 電力中央研究所 電力技術研究所

干240-0196 横須賀市長坂 2-6-1

Electric Power Engineering Research Lab., Central Research Institute of Electric Power Industry (CRIEPI)

2-6-1, Nagasaka, Yokosuka 240-0196

** (財) 電力中央研究所 原子力技術研究所 電力技術研究所/ 東京電機大学

干201-8511 狛江市岩戸北 2-11-1

Nuclear Technology Research Lab., Central Research Institute of

Electric Power Industry (CRIEPI)

2-11-1, Iwado-Kita, Komae 201-8511
}

場合は, 2 種類の誘電体界面と電極が接触する点のいわゆる 「高木効果あるいは 3 重点効果 (triple-junction effect)」(1) (5) がよく知られているが，ここで解析するのは電極と接触し ていないかど(先端)である。

\section{2. 導体かどの電界の解析的検討}

〈2·1〉 かど付近の電界図 1 の二次元配置において 導体外部の電位を $\Phi$ とす。同図の極座標 $(r, \theta$ 座標 $)$ で考 えると, 境界条件は, $\theta=0,2 \pi-\theta_{0}$ で $\Phi=0$ である。ラプラ スの式は,

$$
\frac{1}{r} \frac{\partial}{\partial r}\left(r \frac{\partial \Phi}{\partial r}\right)+\frac{1}{r^{2}} \frac{\partial^{2} \Phi}{\partial \theta^{2}}=0
$$

である。この式を $r, \theta$ に対する変数分離法で解くと,

$A_{n} r^{n} \sin n \theta, B_{n} r^{n} \cos n \theta$ の項が得られる。

境界条件を満足して, しかも $n$ が最小の解を選ぶと,

$$
\Phi=K r^{n} \sin n \theta, \quad n=\pi /\left(2 \pi-\theta_{0}\right)
$$

となる。ここで, $\cos n \theta$ を含む項は境界条件を満足せず, また最小の $n$ を取るのは $\mathrm{P}$ 点近くの, したがって $r$ が 0 に

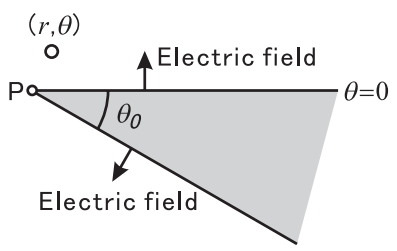

図 1 断面がくさび形状の導体 (極座標表示)

Fig. 1. Wedge-like edge of a conductor (Polar coordinate expression). 
近いときの電界を問題にしているからである。また， $K$ は 全体の配置から決まる定数である。(2)式が正しい電位分布 であることは，「ラプラスの式と境界条件を満足すればた だ一つの正しい解である」という一意性の定理で保証され ている。

$m=n-1$ とすると, 電界の大きさは $r^{m}$ に比例するので, 結 局 $\theta_{0}<\pi$ (凸) であれば $n<1, m<0$, したがって $\mathrm{P}$ 点に近 づくと電界は無限大になる。 $\theta_{0}>\pi$ (回) であれば $n>1, m$ $>0$, したがって $\mathrm{P}$ 点に近づくと電界は 0 になる。

$\theta_{0}=\pi$ であれば電界の特異性はないが， $\theta_{0}<\pi$ のとき， $\theta_{0}$ が小さいほど $m$ は小さくなり, 電界の上昇割合は高くなる。 たとえば直角のかど $\left(\theta_{0}=\pi / 2\right)$ であれば $m=-1 / 3$, 厚みのな い(薄い)䇴であれば $m=-1 / 2$ である。

〈2·2〉 かど付近の電界の緩和前項に述べたよう に, 開き角が 180 度より小さいくさび先端では一般に電界 が無限大である。しかし特別な配置では次のようにして電 界を 0 にすることができる。

(1) 対称性の利用 ${ }^{(6)}$ 図 2 のように電位がそれぞれ $2 \mathrm{~V}$ と 0 である 2 個の導体(電位 0 は大地である)の中間に上下 対称で先端がくさび形状の導体を置く。この中間導体の電 位を $V$ にすれば，対称性から導体外の空間の中間面(図の点 線)の電位も $V$ である。空間の等電位面を同じ電位の導体で 置き換えても電界分布は変わらないので, $\mathrm{P}$ 点は前節で解説 した $\theta_{0}>\pi$ の点に相当し電界は 0 になる。

(2) 第 3 導体の電位変化 ${ }^{(7)} \quad$ 対象としている導体 $\mathrm{A}$ (電 位 $V_{a}$ ） と大地のほかに第 3 の導体 $\mathrm{B}$ （電位 $V_{b}$ ）を考える。 簡単のために, 図 3 のように第 3 導体を平面 (平板) 形状 とする。（a）のように $V_{a}>0, V_{b}=0$ のとき $\mathrm{P}$ 点の電界は無 限大であるが, A 導体からの電気力線はすべて大地あるい は B 導体に至る方向である。次に（b）のように $V_{b}>0, V_{a}$ $=0$ とすると（あるいは $V_{b}$ を $V_{a}$ より充分大きくすると） $\mathrm{P}$

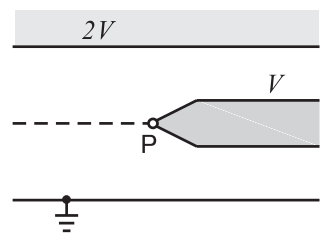

図 2 先端 $\mathrm{P}$ の電界が 0 の配置

Fig. 2. Arrangement for making an electric field zero at an edge tip.

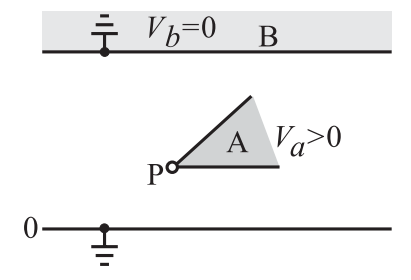

(a) $V_{a}>0, \quad V_{b}=0$

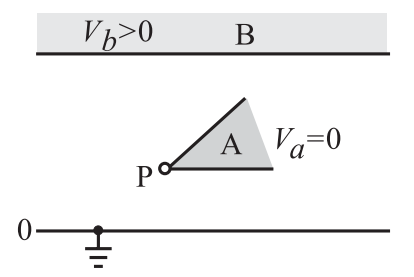

(b) $V_{a}=0, \quad V_{b}>0$
図 3 第 3 導体（電位 $V_{b}$ ) の利用

Fig. 3. Utilization of a third conductor.
点の電界はやはり無限大であるが, 通常は $\mathrm{B}$ 導体からの電 気力線が $\mathrm{A}$ 導体に至る方向になる。すなわち電界あるいは 電気力線の方向が逆転する。

したがって, $V_{b}$ を 0 から上げていくと, $\mathrm{P}$ 点付近の電気 力線と電界の方向が逆転する電圧があり, このときに $\mathrm{P}$ 点 の電界は０になる。（イ）の場合と異なり, この方法では対 象導体の電位を変えることによってどんな配置でも $\mathrm{P}$ 点の 電界を０にできる。

\section{3. 導体かどの電界の数值的検討}

ここでは図 3 のような対称性があるときの配置と異な り, 対称性がない配置について, 導体かどの電界の振る舞 いを調べる。すなわち, 先に述べた平面形状の第 3 導体と 大地 (接地平面)の間にくさび形状の導体（以下，くさび導 体）がある配置において，〈さび導体のかど点の電界が 0 になるように, 平面形状の第 3 導体の電圧 $V_{b}$ とくさび導体 の電圧 $V_{a}$ を数值的に求める。

かど点の電界が 0 になる電圧 $V_{a}, V_{b}$ は種々の組み合わせ がある。 $V_{b}$ を固定すれば $V_{a}$ の值だけを求めればよいが, こ の場合でもかど点の電界が 0 になるような $V_{a}$ の值を求める にはかなりの試行錯誤が必要である。しかし, 静電界の重 畳の理を用いれば, 2 種類の電圧条件の電界を計算するだ けで, かど点の電界が 0 になる $V_{a}, V_{b}$ の組み合わせが求ま る。数值計算では電界が無限大となるかど点は計算できな いので, かど点近傍の電界で検討する。

図 4 (a), (b) に示電位条件 $V_{a}=1, V_{b}=0$ および $V_{a}=0, V_{b}=1$ の配置でくさび導体表面のかど点近傍の電界 $E_{a 0}, E_{0 b}$ を計 算すれば, 同図(c)の任意の $V_{a}, V_{b}$ におけるかど点近傍の電 界 $E_{a b}$ は重畳の理より

$$
E_{a b}=E_{a 0} \cdot V_{a}+E_{0 b} \cdot V_{b}
$$

となる。ここで, $E_{a 0}$ と $E_{0 b}$ の電界の方向は逆であるから, $V_{a} / V_{b}$ の比 $c$ を $\left|E_{0 b} / E_{a 0}\right|$ とすると $E_{a b}$ が 0 になる。

かど点近傍の電界は数值電界計算法の一つである電荷重 畳法により計算した。先に述べたようにかど点で電界が無 限大になり, かど点近傍で電界が急上昇することが考えら れることから, かど点に一定の比で近づくように輪郭点を 配置することとし, 輪郭点と仮想電荷の位置は図 5 に示す パラメータにおいて, 以下の式で与えられる $H_{i}$ と $L_{i}$ を用い た。

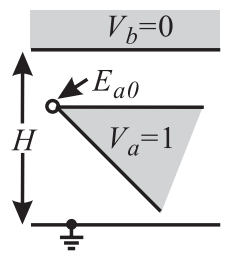

(a) $V_{a}=1, V_{b}=0$

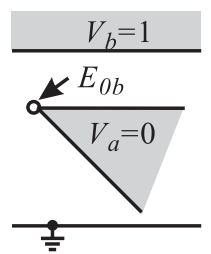

(b) $V_{a}=0, V_{b}=1$

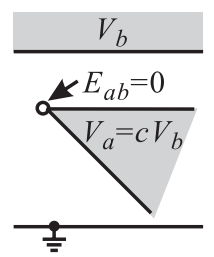

(c) $V_{a}=c V_{b}\left(c=\left|E_{0 b} / E_{a 0}\right|\right)$
図 4 かど点の電界が 0 になる電位 $V_{a}$ と $V_{b}$ の

組み合わせ

Fig. 4. Combination of $V_{a}$ and $V_{b}$ making an electric field zero at an edge tip. 


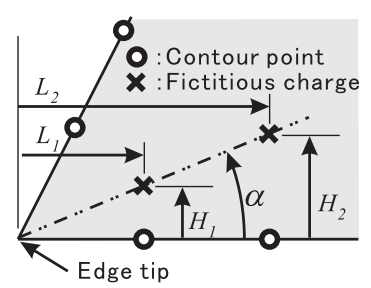

図 5 くさび導体の輪郭点と仮想電荷

Fig. 5. Arrangement of contour points and fictitious charges for a wedge-like edge.

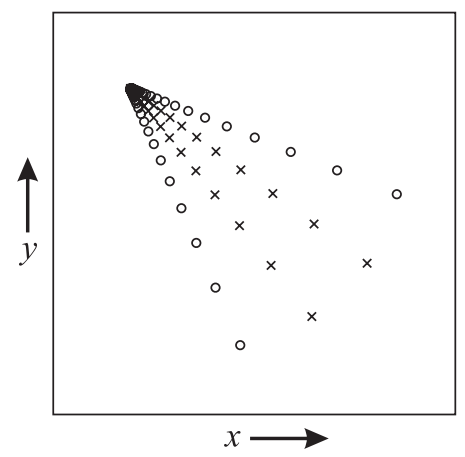

図 6 くさび導体の輪郭点と仮想電荷の配置例

Fig. 6. An example of arrangement of contour points and fictitious charges.

$L_{i}=\left(\frac{1.2}{1.2-\tan \alpha}\right)^{i-1} L_{l}$

$H_{i}=1.2\left(L_{i}-L_{i-1}\right)=L_{i} \tan \alpha$

ここで， $\alpha$ は与える角度で, くさびの開き角の $1 / 3$ を与える。 $\alpha$ を $15^{\circ}$ としたときのくさび導体の輪郭点と仮想電荷の配 置例を図 6 に示す。なお，かど点にもつとも近い輪郭点と かど点との距離 $L_{1}$ は $L_{1} / H=0.7 \times 10^{-9}(H$ は平面導体と大地間 の距離)である。

くさびの開き角 $\theta$ を $45^{\circ}$ としたくさび導体の計算配置を 図 7 に示す(7)。図 7 (a)で，〈さび導体の中心軸と $\mathrm{y}$ 軸との角 度 $\theta$ が $0^{\circ} ， 37.5^{\circ} ， 67.5^{\circ} ， 97.5^{\circ}$ の場合について，かど 点近傍の電界が 0 になるときの $V_{a}$ と $V_{b}$ の比 $c\left(=V_{a} / V_{b}\right)$ を求 めた。導体の影響は, 平面導体とくさび導体双方の形状や 寸法の影響が考えられ, 表 1 の值はあくまでも図 7 (a) の具 体的な配置に対する值である。図 7 (b) は輪郭点配置である。 平面導体と大地の間隔 $\mathrm{H}$ に対して, かど点を中心に横方向 $-3 H \sim 5 H$ の範囲に輪郭点を配置した。くさび電極の下側面 はほぼ接地平面に近い位置までである。また平面導体の効 果については, 平面導体のみとしたときのかど点近傍の電 界は平均電界 $\left(V_{b} / H\right)$ と $0.001 \%$ 差であり, 平面導体の端部の 影響はほとんどない。結果を表 1 に示す。また, 電圧 $V_{a}$, $V_{b}$ を表 1 の比にしたときのくさび導体表面の電界分布を図 8 に示す。図 8 以下の電界は全て平均電界 $V / H$ で規格化し ている。

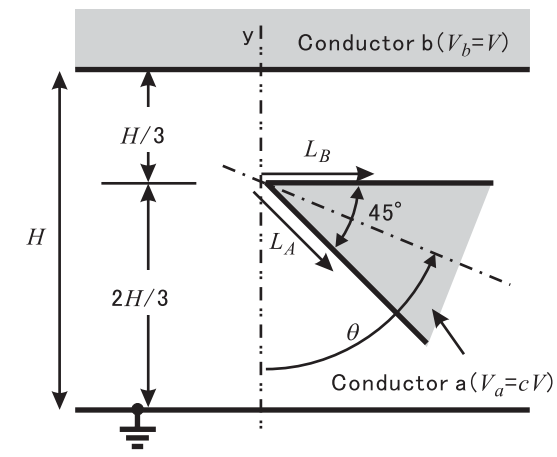

(a) Calculation model

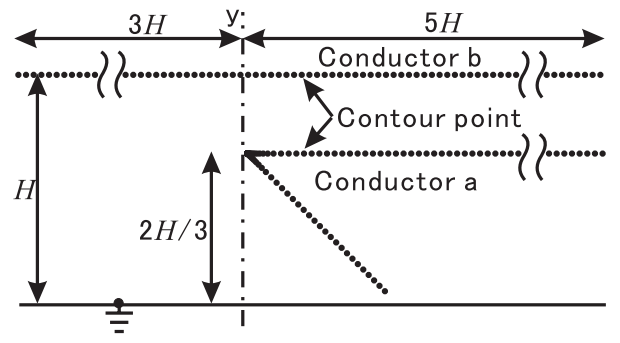

(b) Contour points

図 7 くさび導体の計算配置 ${ }^{(7)}$

Fig. 7. Calculation arrangement for a conductor edge $\mathrm{e}^{(7)}$.

表 1 かど点近傍の電界が 0 になる $V_{a}$ と $V_{b}$ の比 Table 1. Ratio of $V_{a} / V_{b}$ when electric field is zero near an edge tip.

\begin{tabular}{|c|c|}
\hline$\theta\left(^{\circ}\right)$ & $c\left(=V_{d} / V_{b}\right)$ \\
\hline 0 & 0.92825 \\
\hline 37.5 & 0.86836 \\
\hline 67.5 & 0.76816 \\
\hline 97.5 & 0.46506 \\
\hline
\end{tabular}

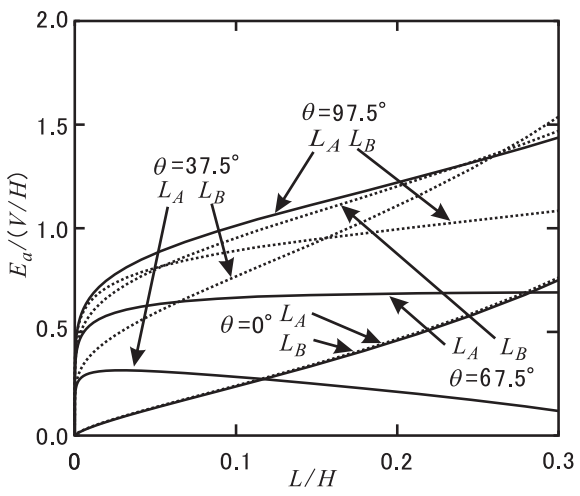

図 8 くさび導体上の電界分布

Fig. 8. Electric field distribution on the side surface of the edge.

図 8 の横軸はかど点からの距離, 縦軸はくさび導体上の 電界である。同図によれば，かど点からの距離が 0 に近く なると実際に電界が増大せずに急激に小さくなっている。

\section{4. 誘電体かどの電界の解析的検討}

〈4・1〉 かど付近の電界 ${ }^{(8)}$ 図 9 の二次元配置を, 図 


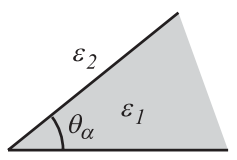

図 92 誘電体のくさび形状界面

Fig. 9. Wedge-like edge of a dielectric interface.

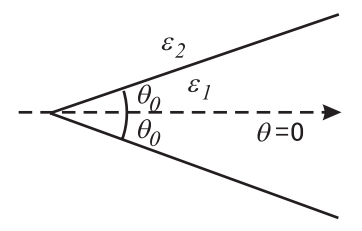

図 10 図 9 の極座標表示

Fig. 10. Polar coordinate expression of Fig.9.

10 のように先端を原点とし，〈さびの中間面を $\theta=0$ とする 極座標 $(r, \theta$ 座標）で考える。変数分離法を適用すると誘 電体 $\varepsilon_{1}, \varepsilon_{2}$ における電位 $\Phi_{1}, \Phi_{2}$ を次の級数解で与えること ができる。

$$
\left.\begin{array}{l}
\Phi_{1}=\sum_{n=-\infty}^{\infty} r^{n}\left(a_{n} \cos n \theta+b_{n} \sin n \theta\right) \\
\Phi_{2}=\sum_{n=-\infty}^{\infty} r^{n}\left(c_{n} \cos n \theta+d_{n} \sin n \theta\right)
\end{array}\right\}
$$

境界条件は, $\theta=\theta_{O}$ ならびに $\theta=-\theta_{O}$ で $\Phi_{1}=\Phi_{2}, \varepsilon_{l}\left(\partial \Phi_{1} / \partial \theta\right)=\varepsilon_{2}\left(\partial \Phi_{2} / \partial \theta\right)$ である。

これらから，

$$
\begin{aligned}
& \left.a_{n} \cos n \theta_{0}+b_{n} \sin n \theta_{0}=c_{n} \cos n \theta_{0}+d_{n} \sin n \theta_{0}\right) \\
& \varepsilon_{I}\left(a_{n} \sin n \theta_{0}-b_{n} \cos n \theta_{0}\right) \\
& \quad=\varepsilon_{2}\left(c_{n} \sin n \theta_{0}-d_{n} \cos n \theta_{0}\right) \\
& a_{n} \cos n \theta_{0}-b_{n} \sin n \theta_{0}=c_{n} \cos n\left(2 \pi-\theta_{0}\right) \\
& \quad+d_{n} \sin n\left(2 \pi-\theta_{0}\right) \\
& \varepsilon_{1}\left(a_{n} \sin n \theta_{0}+b_{n} \cos n \theta_{0}\right) \\
& \quad=\varepsilon_{2}\left\{-c_{n} \sin n\left(2 \pi-\theta_{0}\right)+d_{n} \cos n\left(2 \pi-\theta_{0}\right)\right\}
\end{aligned}
$$

(6)式において，係数 $a_{n} ， b_{n}, c_{n}, d_{n}$ が 0 でない有意な解を 持つためには，係数行列式が 0 にならなければならない。 すなわち, $n \theta_{0}=A, n\left(2 \pi-\theta_{0}\right)=B$ と書くと，

$$
\left|\begin{array}{cccc}
\cos A & \sin A & -\cos A & -\sin A \\
\cos A & -\sin A & -\cos B & -\sin B \\
\varepsilon_{1} \sin A & -\varepsilon_{1} \cos A & -\varepsilon_{2} \sin A & \varepsilon_{2} \cos A \\
\varepsilon_{1} \sin A & \varepsilon_{1} \cos A & \varepsilon_{2} \sin B & -\varepsilon_{2} \cos B
\end{array}\right|=0
$$

分解して整理すると, この行列式 $T$ は,

$$
\begin{aligned}
T= & 2 \varepsilon_{1} \varepsilon_{2}-2 \varepsilon_{l} \varepsilon_{2} \cos 2 A \cos (A-B) \\
& -\left(\varepsilon_{1}^{2}+\varepsilon_{2}^{2}\right) \sin 2 A \sin (A-B)=0
\end{aligned}
$$

となる。さらに変形すると,

$$
\begin{aligned}
& T=4 \varepsilon_{1} \varepsilon_{2} \tan ^{2} A\left(\frac{\tan C}{\tan A}-\frac{\varepsilon_{2}}{\varepsilon_{1}}\right)\left(\frac{\tan C}{\tan A}-\frac{\varepsilon_{1}}{\varepsilon_{2}}\right)=0 \\
& \text { ここで } C=(A-B) / 2=n\left(\theta_{0}-\pi\right)
\end{aligned}
$$

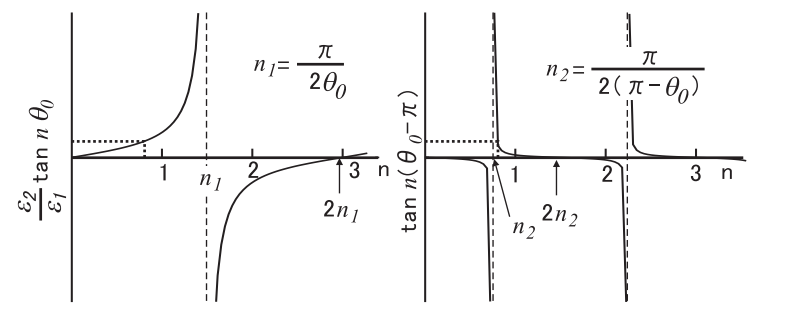

図 $11\left(\varepsilon_{2} / \varepsilon_{1}\right) \tan n \theta_{0}, \tan n\left(\theta_{0}-\pi\right)$ のグラフ

Fig. 11. Curves of $\left(\varepsilon_{2} / \varepsilon_{1}\right) \tan n \theta_{0}$ and $\tan n\left(\theta_{0}-\pi\right)$.

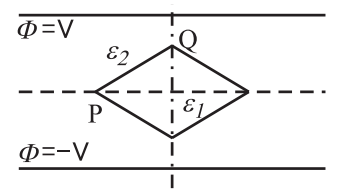

図 12 上下左右対称な配置

Fig. 12. Symmetrical arrangement for a dielectric edge.

すなわち, 次の 2 つのケースになる。

(i) $\frac{\tan C}{\tan A}=\frac{\tan n\left(\theta_{0}-\pi\right)}{\tan n \theta_{0}}=\frac{\varepsilon_{2}}{\varepsilon_{1}}$

(ii) $\frac{\tan C}{\tan A}=\frac{\varepsilon_{1}}{\varepsilon_{2}}$

図 11 によれば(i),(ii)の超越方程式は $n=1$ 付近に解(左右の 曲線の交点, 点線箇所)を有するので, $r=0$ (かど点) 付近では (i)または(ii)の解の夕考えればよい。例えば(i)の場合, $f(n)=\left(\varepsilon_{2} / \varepsilon_{\nu}\right) \tan n \theta_{0}-\tan \left(\theta_{0}-\pi\right)$ を考えると, $f(1)=\tan \theta_{0}\left(\varepsilon_{2} / \varepsilon_{1}\right.$ - 1)なので, $\theta_{0}<\pi / 2$ であるから $\varepsilon_{2}>\varepsilon_{1}$ のときに $0<n<1$ の解を 持つことが分かる。

〈4·2〉 かど部の電界緩和 〈2·2〉節に述べた, 導体か どの場合と同様に，丸みのない，〈さび形状の誘電体界面 先端電界を 0 にできる可能性がある。誘電体界面の場合に は次の二つの方法が考えられる。

（1）対称性の利用 二次元の配置を考える。図 12 の ように電位がそれぞれ $V$ とー $V$ である 2 個の平板電極(導体) の中間に, 上下左右対称で 4 つ先端がくさび形状の誘電 体界面 $\left(\varepsilon_{1}>\varepsilon_{2}\right)$ を配置する。完全に上下対称であれば, 中間面 (図の点線)の電位が 0 となり, 等電位面を同じ電位の導体 で置き換えても電界分布は変わらないので, $\mathrm{P}$ 点は接触点電 界の高木効果に相当し電界は 0 になる。また完全に左右対 称であれば, 中間面 (図の一点鎖線)が電界(電気力線)の方 向と一致し, $\mathrm{Q}$ 点の電界は無限大になる ${ }^{(7)}$ 。図 12 で上部電 極の電位が $2 V$, 下部電極の電位が 0 でも, 全体の電位が $V$ だけあがる(シフトする)だけで電界は同じである。このと き $\mathrm{P}$ を通る中間面の電位は $V$ になる。

（2）対称性のない場合（一般的な場合）導体の場合 と異なり, 誘電体は一定電位ではなく, またその電位を容 易に変えられない。この場合, その代わりに位置を変えら れるとする。まず, 無限大電界は局所的な電荷状態（この 場合は分極電荷）によって発生することに注意する。外部 から印加された電界, すなわち電極表面に存在する電荷だ 


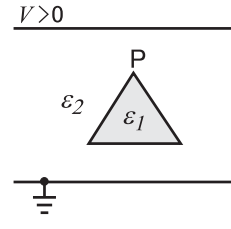

(a) Upward direction

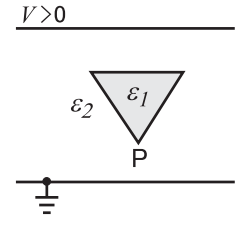

(b) Downward direction
図 $13 \varepsilon_{2}$ 中のくさび状誘電体 $\varepsilon_{1}$

Fig. 13. Dielectric $\varepsilon_{1}$ inside dielectric $\varepsilon_{2}$.

けでは P 点で無限大電界を形成できない。

図 13 のように， $\varepsilon_{1}$ が $\varepsilon_{2}$ より大きい場合（誘電体凸部）の 先端 $\mathrm{P}$ の電界を考える。同図の (a), (b)の $\mathrm{P}$ 点ではともに理 論上電界無限大であるが， $\varepsilon_{1}$ から $\varepsilon_{2}$ の方向を正にとると， $\mathrm{P}$ 点付近の電界は(a)では負の無限大，(b)では正の無限大であ る。したがって, 誘電体 $\varepsilon_{1}$ を回転させると, 先端電界が負か ら正の無限大に変化する角度があり，このときの角度で (一 瞬）電界は 0 になるはずである。これは対称的な配置の図 12 の $\mathrm{P}$ 点に相当する。

\section{5. 誘電体かどの電界の数值的検討}

ここでは図 12 のような対称性があるときの配置と異な り，対称性がない配置について，誘電体かどの電界の振る 舞いを調べる。すなわち, 先に述べた図 13 のくさび形状の 誘電体と平板状電極 (導体) の配置で，くさび形状の誘電体 先端のかど点の電界が 0 になる配置を検討する。くさび形 状誘電体のくさびの開き角を $45^{\circ}$ とし，かど点を中心にく さび形状誘電体を回転して，回転角に対するかど点近傍の 電界を求める。計算の配置を図 14 に示す。誘電体の比誘電 率 $\varepsilon_{1}$ は 6 で, 誘電体以外の平板状電極 (導体) と大地の間の比 誘電率 $\varepsilon_{2}$ は 1 である。以下では電界は全て平均電界 $V_{d} / H$ で 規格化した值である。図 15 は誘電体の種々の回転角 $\theta$ にお いて，かど点に近い 3 点の電界值を示したものである。こ の図によれば回転角 $\theta$ が $85^{\circ}$ 付近のときに電界が 0 にな る。このくさび形状の誘電体の配置ではかど点の電界が 0 となるときは図 12 に近い角度であるが, 図 12 のように $\theta=90^{\circ}$ でないのは，配置が上下非対称なためである。図 16 に図 14 の配置で回転角 $\theta$ が $85^{\circ}$ のときの等電位面を示す。 数值計算上，かど点の電界が完全に 0 になる $\theta$ を求めるのは 困難であり, 回転角 $\theta$ が $85^{\circ}$ の場合もかど点の電界は 0 で はないが，かど点の電界が完全に 0 になる回転角 $\theta$ であれ ば，かど点を通る等電位面はかどの中間面（開き角の $1 / 2$ ) を通りそうである。

図 17 は図 14 の $\varepsilon_{1}$ と $\varepsilon_{2}$ を入れ替えた配置の結果で, $\varepsilon_{1}<\varepsilon_{2}$ であるので, 理論的には左右対称なので回転角が $0^{\circ}$ のとき にかど点の電界が 0 になる。図によれば実際に $\theta=0^{\circ}$ で電界 は 0 になり，また 0 のとき以外では電界が 0 になるような 傾向はない。これらの結果より，くさび形の凸形状 $\left(\varepsilon_{l}>\varepsilon_{2}\right)$ あるいは凹形状 $\left(\varepsilon_{1}<\varepsilon_{2}\right)$ の誘電体の開き角を固定した配置で は，かど点の電界が 0 になるときの回転角 $\theta$ は一つ $(\mathrm{y}$ 軸で 対称な場合も入れれば二つ)だけであると考えられる。

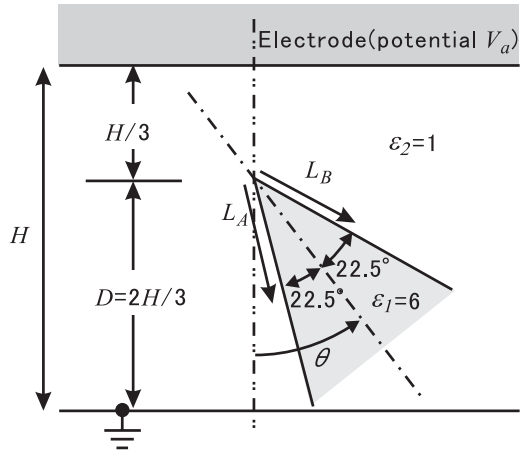

図 14 くさび状誘電体計算配置

Fig. 14. Calculation arrangement for a wedge-like edge of a dielectric interface.

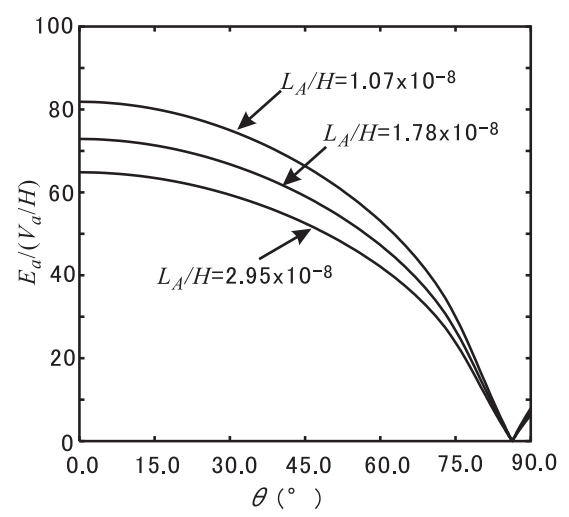

図 15 かど点近傍の電界 (くさび部分 $45^{\circ}$ )

Fig. 15. Electric field near an edge tip.

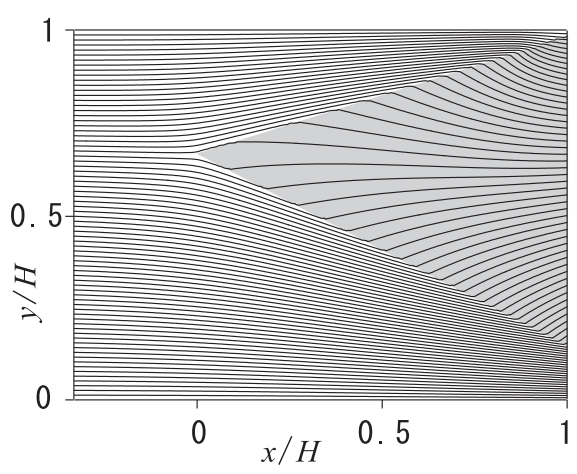

図 16 困 14 の等電位線 $\left(\theta=85^{\circ}\right)$

Fig. 16. Equipotential lines for Fig.14.

図 18 は図 17 の凹形状の誘電体について, 凹部の開き角 $\theta$ を変えて凹点の電界を検討した配置である。 $\varepsilon_{I}=1, \varepsilon_{2}=6$ のと きは $\varepsilon_{1}<\varepsilon_{2}$ であるから，凹点の電界は通常無限大である。 $\theta=180^{\circ}$ のときはもちろん凹点の電界は無限大にならない が，それ以外の角度で電界が低くなる開き角を調べる。こ れまでの検討から, 凹点を通る電気力線が中間面 $(\theta$ の $1 / 2$ の角度)を通れば，凹点の電界が 0 になる可能性がある。

図 19 に凹点近傍の 3 点における開き角 $\theta$ に対する電界 $\left(V_{d} / H\right.$ による規格值 $)$ を示す。図によれば $\theta$ が $160^{\circ}$ 程度のと 


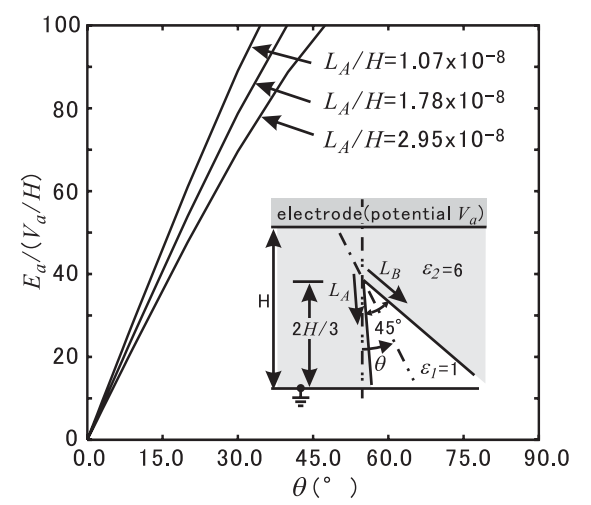

図 17 凹点近傍の電界 (部の開き角 $45^{\circ}$ )

Fig. 17. Electric field near a wedge-like dent.

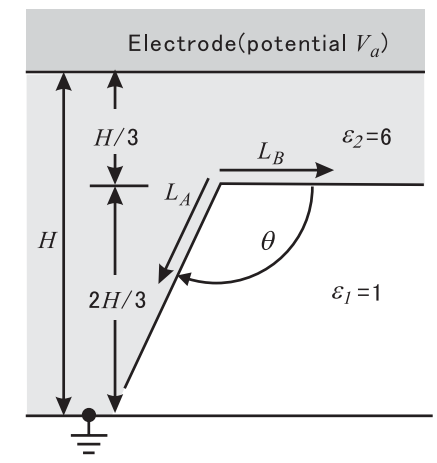

図 18 凹形状誘電体の開き角 $\theta$ を変える配置

Fig. 18. Calculation arrangement for a wedge-like dent.

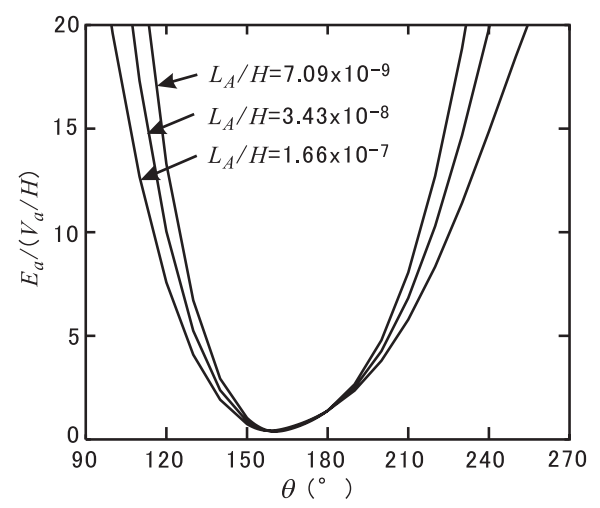

図 19 開き角と凹点近傍の電界

Fig. 19. Electric field near an edge tip.

きにもつとも電界が小さい。開き角 $\theta$ が $150^{\circ}, 160^{\circ}, 170^{\circ}$, $180^{\circ}$ における凹点近傍の電界分布を図 20 に示す。開き角 $\theta$ が $180^{\circ}$ のときは凹点近傍の電界はほぼ一定で, $\left(V_{d} / H\right) \times$ (18/13) である。 $\theta$ が $150^{\circ}$ のときは $L / H$ が $10^{-4} \sim 10^{-5}$ までは 電界が減少寸るが, 凹点にもっと近く $(L / H$ が小さく $)$ なると 電界が増加する傾向になる。また， $\theta$ が $160^{\circ}$ のときは凹点 に近くなるにつれて電界は減少しているが, $\mathrm{L} / \mathrm{H}=10^{-8}$ 程度で 電界の減少の割合が小さくなる。 $\theta$ が $170^{\circ}$ のときは図では ほぼ直線的に減少しており, 開き角が $160 \sim 170^{\circ}$ 付近のと

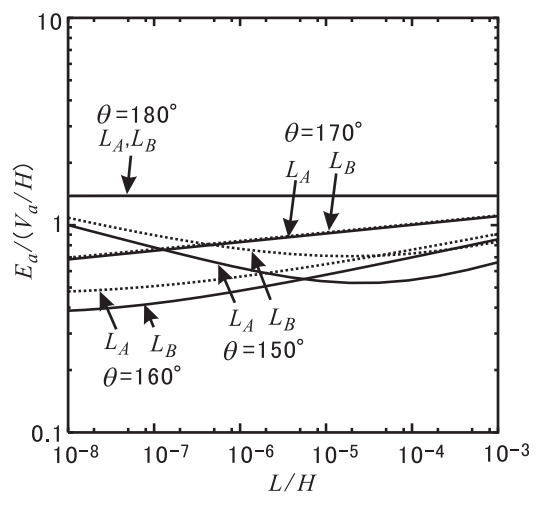

図 20 凹点近傍の電界分布

Fig. 20. Electric field distribution for Fig.19.

き凹点で電界が 0 になりそうである。このように配置の非 対称性により, 開き角が $180^{\circ}$ の電界よりかど点の電界が低 くなる配置がある。

\section{6. まとめ}

本論文では電界が通常は無限大となる導体や誘電体のか どについて，かど点（あるいは凹点）の電界を緩和し，か ど点（凹点）の電界を 0 とする方法について述べ，実際に この電界緩和現象を数值計算で確かめた。導体のかどは第 3 導体を用いて, かどがある導体の電圧と第 3 導体の電圧 をある比率にすれば，かど点の電界を 0 にすることができ る。このときの電圧值は重畳の理を用いれば容易に求めら れる。一方, 誘電体のかどは誘電率が大きい方の誘電体の かどを考えると, 凸点の場合はかど点を通る等電位面がか どの中間面(開き角の $1 / 2$ )を通る配置, 凹点の場合は電気力 線が中間面を通る配置のときに電界が 0 になると考えられ る。実際に色々な配置で電界が小さくなることを数值計算 によって確かめた。

(平成 16 年 4 月 20 日受付, 平成 16 年 7 月 29 日再受付)

\section{文献}

(1) 高木純一：「導体並びに絶縁体の尖端における電界について」, 早稲 田大学電気工学会雑誌, pp.69-77 (4 月), pp.103-110 (5 月), pp.139-147 (6 月), pp.206-213 (8 月) (1939)

(2) T.Takuma, T.Kouno, H.Matsuba, T.Watanabe, and T.Kawamoto : "On the field distribution at the boundary surface of two dielectrics having a straight section", CRIEPI Report, No.176002 (1976) (in Japanese)

宅間 董・河野照哉・松葉博則・渡辺恒雄・河本 正 :「直線上の誘 電体境界面(境界面)における電界について」, 電中研報告, No.176002 (1976)

(3) J.Meixner : "The Behavior of Electromagnetic Fields at Edges", IEEE Trans. Antennas Propagat., Vol.20, No.4, pp.442-446 (1972)

(4) T.Takuma : "Field Behavior at a Triple Junction in Composite Dielectric Arrangements", IEEE Trans. Elect. Insul., Vol.EI-26, No.3, pp.500-509 (1991-6)

（5）宅間 董:「複合誘電体における電界集中」, 静電気学誌, Vol.14, No.1, pp.40-48 (1990-1)

(6) T.Takuma : "Check your reasoning on electromagnetic fields - Tricky Technical Trivia", IEEE Power Eng. Rev., Vol.14, No.2, pp.36-39 (1994)

(7) 宅間 董: 電界パノラマ, 電気学会 (2003)

（8）宅間 董・河本 正: 固体誘電体中のボイド角部の電界, 平成元年 電気学会全国大会, No.22 (1989) 


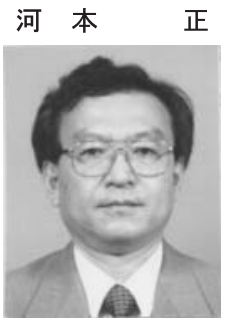

（正員） 1953 年 11 月 26 日生。 1974 年 3 月奈 良工業高等専門学校電気工学科卒業。1979 年 3 月東京理科大学 II 部物理学科卒業。1 1974 年 4 月(財)電力中央研究所入所。主として、電界 磁界計算法に関する研究に従事し、現在に至 る。博士(工学)。1989 年および 2001 年電気学 会論文賞受賞。IEEE 会員。
宅 間 董 （正員） 1938 年 9 月 30 日生。1966 年東京大

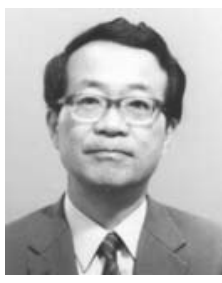

学大学院博士課程修了。工学博士。同年同大学 電気工学科講師。1967 年(財)電力中央研究所入 所。高電圧, 放電, 電磁界解析, 核融合などの 研究に従事。1989 1993 年九州大学客員教授。 1995 年 2002 年京都大学工学研究科教授。 2002 年から(財)電力中央研究所研究顧問。2004 年東京電機大学教授。1975 年英国電気学会 Maxwell 賞, 1981 年および 1991 年電気学会著作賞, 1992 年業績 賞受賞ならびに科学技術庁長官賞受賞。IEEE Fellow. 